\title{
Clinical-based Cell Therapies for Heart Disease-Current and Future State
}

\author{
Darren Turner, B.A. ${ }^{1}$, Angela C. Rieger, M.S., M.D. ${ }^{1}$, Wayne Balkan, Ph.D. ${ }^{1,2}$, \\ and Joshua M. Hare, M.D. ${ }^{1,2 *}$ \\ ${ }^{\prime}$ Interdisciplinary Stem Cell Institute, University of Miami Miller School of Medicine, Miami, Florida, \\ USA; and Department of Medicine, University of Miami Miller School of Medicine, Miami, Florida, \\ $U S A$
}

\begin{abstract}
Patients have an ongoing unmet need for effective therapies that reverse the cellular and functional damage associated with heart damage and disease. The discovery that $\sim \mathbf{1} \%-\mathbf{2} \%$ of adult cardiomyocytes turn over per year provided the impetus for treatments that stimulate endogenous repair mechanisms that augment this rate. Preclinical and clinical studies provide evidence that cell-based therapy meets these therapeutic

Abbreviations: AMI, acute myocardial infarction; BMMNCs, bone marrow-derived mononuclear stem cells; BNP, brain natriuretic peptide; CDCs, cardiosphere-derived cells; CPSCs, cardiopoietic stem cells; CSCs, cardiac stem cells; CVD, cardiovascular disease; EDV, end diastolic volume; EPCs, endothelial progenitor cells; ESCs, embryonic stem cells; ESV, end systolic volume; HSCs, hematopoietic stem cells; iPSCs, induced pluripotent stem cells; ICM, ischemic cardiomyopathy; LVEF, left ventricular ejection fraction; MI, myocardial infarction; MSCs, mesenchymal stem cells; NIDCM, non-ischemic dilated cardiomyopathy; QoL, quality of life; 6MWD, 6-minute walk distance; TESI, transendocardial stem cell injection.
\end{abstract}

Citation: Turner D, Rieger AC, Balkan W, Hare JM. Clinical-based Cell Therapies for Heart Disease-Current and Future State. Rambam Maimonides Med J 2020;11 (2):eo015. Review. doi:10.5041/RMMJ.10401

Copyright: (C) 2020 Turner et al. This is an open-access article. All its content, except where otherwise noted, is distributed under the terms of the Creative Commons Attribution License (http://creativecommons.org/licenses/by/3.o), which permits unrestricted use, distribution, and reproduction in any medium, provided the original work is properly cited.

Acknowledgements: This work was funded by grants, Ro1 HL107110, Ro1 HL134558, 5UM 1HL113460, and Ro1 HL137355 from the National Institutes of Health (NIH), W81XWH-19-PRMRP-CTA from the Department of Defense (DOD) and by the Marcus Foundation, the Soffer Family and the Starr Foundation.

Conflict of interest: Dr Joshua Hare reports having a patent for cardiac cell-based therapy. He holds equity in Vestion Inc. and maintains a professional relationship with Vestion Inc. as a consultant and member of the Board of Directors and Scientific Advisory Board. Dr Hare is the Chief Scientific Officer, a compensated consultant, and advisory board member for Longeveron and holds equity in Longeveron. Dr Hare is also the co-inventor of intellectual property licensed to Longeveron. The other authors report no conflicts.

* To whom correspondence should be addressed. E-mail: jhare@med.miami.edu 
criteria. Recent and ongoing studies are focused on determining which cell type(s) works best for specific patient population(s) and the mechanism(s) by which these cells promote repair. Here we review clinical and preclinical stem cell studies and anticipate future directions of regenerative medicine for heart disease.

KEY WORDS: Cell therapy, ischemic cardiomyopathy, non-ischemic cardiomyopathy, stem cells

\section{INTRODUCTION}

The leading cause of death by non-communicable disease in the world is cardiovascular disease (CVD), and the American Heart Association estimates that over half of all Americans above the age of 40 suffer from CVD, much of it hypertension-related. ${ }^{1}$ While the number of Americans dying from CVD was decreasing, that trend began reversing in 2012. ${ }^{1} \mathrm{Cur}-$ rent treatments for CVD focus primarily on slowing disease progression or ameliorating pre-existing myocardial damage; however, the field lacks interventions that fundamentally reverse the progressive nature of CVD. Many patients with end-stage heart damage will require a heart transplant, ${ }^{1}$ yet there is a profound shortage of donors, ${ }^{2}$ illustrating the tremendous need for alternative/novel therapies.

One such approach is stem cell or cell-based therapy, a relatively new frontier in biomedical research that has sparked much debate and controversy in cardiovascular medicine.3,4 The heart was once thought to be incapable of regeneration, but the current consensus is that $\sim 1 \%-2 \%$ of cardiomyocytes turn over each year with a rate that decreases with age. Cardiac remodeling has been characterized by a persistent inflammatory reaction after acute stress and during chronic pathologies, 5 increased oxidative stress, ${ }^{5}$ myocyte apoptosis, ${ }^{6}$ imbalanced oxygen consumption, energy metabolism and extracellular matrix formation contributing to scar formation, 7 endothelial dysfunction, ${ }^{8}$ and decreased capillary density and neovascularization. ${ }^{9}$ Stem cells and other cell-based therapies hold promise to counteract these effects and promote cardiac repair. Stem cells, strictly defined, possess the properties of both self-renewal and differentiation, whereas other cellbased approaches act through the transmission of factors that stimulate endogenous regenerative pathways. Current data support the idea that both approaches improve cardiac structure and function, and this implication of cardiac repair has spurred much excitement in the field. ${ }^{10} \mathrm{~A}$ current great debate is whether engraftment and differentiation of exogenously administered pluripotent stem cells is a requirement for a therapeutic response, with some investigators arguing that it is an essential requirement for a therapeutic response. ${ }^{11,12}$ This controversy is intensified by the observation that pluripotent stem cell therapies produce ventricular arrhythmias in preclinical, large-animal models, ${ }^{11,13,14}$ delaying clinical testing and the ability to compare these approaches with non-pluripotent cell-based therapies, which enjoy a substantial safety profile.

Clinical trials have assessed the safety and feasibility of cell-based therapy, largely testing cultureexpanded cells from bone marrow, adipose tissue, or the heart itself. While initial studies demonstrated positive results, some trials have produced little or no functional improvements in cardiac performance. A majority of studies have focused on surrogate primary end points, such as changes in left ventricular ejection fraction (LVEF) and cardiac volumes, but in some studies only small improvements ( $5 \%$ on average) were seen, which has dampened enthusiasm toward the field. ${ }^{15-17}$ However, substantial efforts continue toward improving cell-based approaches for cardiac repair. Here, we will review clinical trials of cell-based therapy for heart disease and speculate on potential future directions of regenerative cardiovascular medicine.

\section{MECHANISMS OF ACTION}

As mentioned above, a debate currently exists as to whether cell engraftment and differentiation is a requirement for a therapeutic response. Existing data suggest that functional and clinical responses can result from cell therapy using cell types that lack significant myocyte differentiation capacity. ${ }^{18-20}$ However, there is little evidence that stem cells engraft into the target tissue in the long term, suggesting a primarily paracrine mechanism of action. ${ }^{21,22}$ Indeed, secretions of exosomes, growth factors, cytokines, and metalloproteinases are mechanisms that contribute to the regenerative capacity of cells. ${ }^{21-23}$ Stem cells also interact with host cells via heterocellular coupling, wherein the cells communicate directly through gap junctions and tunneling nano- 
tubes to transfer small molecules and mitochondria, respectively. ${ }^{21,24}$ However, a lack of a complete understanding of the mechanisms involved should not preclude clinical studies for evaluating efficacy.

Initial or first-generation stem cells were/are derived from adult tissues, such as those isolated by bone marrow aspiration, and comprise either mixtures of different progenitor cell types, such as unfractionated bone marrow-derived mononuclear cells (BMMNCs), a heterogeneous population of stem cells, or more pure stem cell populations, many of which were isolated from BMMNCs (Figure 1). This latter group of cells includes hematopoietic stem cells (HSCs), mesenchymal stem cells (MSCs), endothelial progenitor cells (EPCs), and others. ${ }^{26}$ Mesenchymal stem cells, initially isolated from bone marrow, have been isolated from multiple tissues including adipose tissue, dental pulp, placenta, umbilical cord blood, and Wharton's jelly. ${ }^{27,28}$ Mesenchymal stem cells exhibit properties important for a reparative cell, including immunomodulation ${ }^{29,30}$ and antifibrotic, ${ }^{31}$ proangiogenic, and anti-oxidative effects, all of which provide support for their being ideal

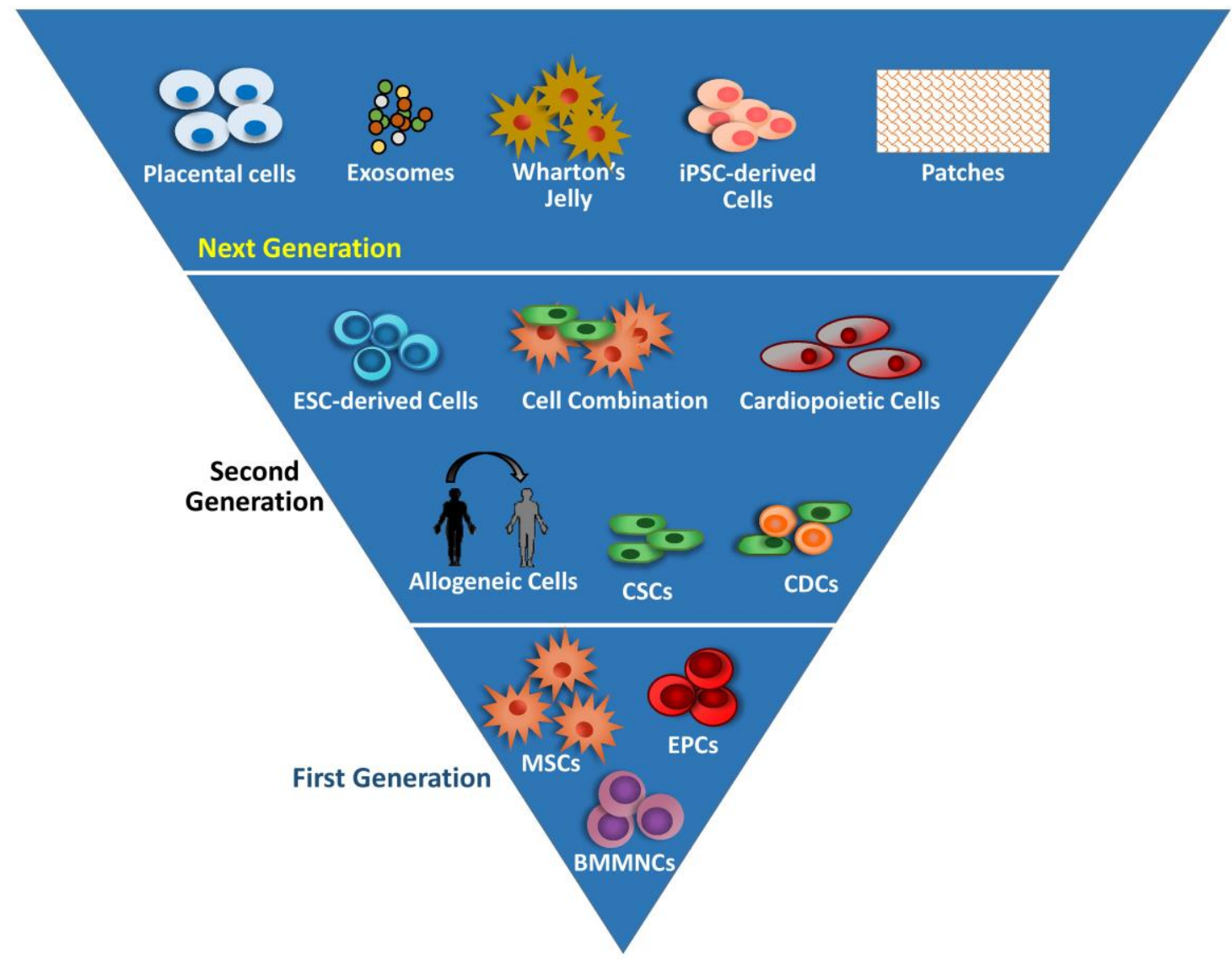

Figure 1. Advances in Cardio-regenerative Medicine.

First-generation stem cell therapy utilized heterogeneous populations of cells, such as BMMNCs and more purified MSCs and EPCs isolated from either bone marrow or blood. Second-generation stem cells include purified cardiac cell populations such as c-kit ${ }^{+}$CSCs and CDCs, ESC-derived cells, allogeneic cells, cardiopoietic cells, and combinations of stem cells. Proposed next-generation approaches will utilize placenta and umbilical cord (Wharton's jelly) cells, iPSC-derived cells, stem cell-derived exosomes, and cell-containing patches.

ADRC, adipose-derived regenerative cell; BMMNC, bone marrow mononuclear cell; CDC, cardiosphere-derived cell; CSC, cardiac stem cell; ESC, embryonic stem cell; iPSC, induced pluripotent stem cell; MSC, mesenchymal stem cell. Adapted from Figure 3 of Banerjee et al. ${ }^{25}$ used with permission. The Creative Commons license does not apply to this content. Use of the material in any format is prohibited without written permission from the publisher, Wolters Kluwer Health, Inc. Please contact permissions@lww.com for further information. 
candidates for treatment of cardiomyopathies. Furthermore, the lack of MHC class antigens confers immunoprivileged characteristics that make MSCs suitable for allogeneic therapy. ${ }^{18}$ Endothelial progenitor cells are primarily bone marrow-derived circulating progenitor cells characterized by the surface markers CD34 and CD133. ${ }^{26}$ Endothelial progenitor cell characteristics associated with their regenerative capacity include migration to injured areas to restore the endothelial niche, their proangiogenic properties, and ability to improve endothelial function. ${ }^{2}$

Second-generation cell therapies include cardiaccommitted progenitor cells, that are lineage-directed by either genetic or secondary modifications to acquire a specific phenotype, or pluripotent stem cells (PSCs). Cardiac-committed progenitor cells include c-kit ${ }^{+}$cardiac stem cells (CSCs). These clonogenic and multipotent cells can differentiate under secondary injury, contributing to organ regeneration. In vitro, CSCs display strong paracrine signaling and multilineage transdifferentiation, making them suitable for cardiac regeneration.33 Cardiospherederived cells (CDCs) are a heterogeneous population of cells isolated from myocardial tissue; they comprise CSCs and support cells and are capable of forming self-adherent clusters in vitro. ${ }^{34,35}$ These cells exhibit multilineage as well as clonogenic characteristics. Cardiopoietic cells are lineagedirected MSCs treated with multiple growth factors to bolster their stemness potential and differentiation. ${ }^{36}$

The PSCs (embryonic stem cells [ESCs] and induced pluripotent stem cells [iPSCs]) have the greatest multilineage capabilities $37-39$; however, the risk of teratoma formation requires that these cells first undergo lineage-directed differentiation prior to transplantation. ${ }^{40,41}$ Additional post-transplantation concerns include the risk of arrhythmias ${ }^{11,13,14}$ and rejection by the recipient. In preclinical studies these cells have demonstrated variable effects on the restoration of cardiac function. ${ }^{11,13,14}$

Third-generation therapy includes genetic reprogramming, exosomes, microRNA (miRNA), and the use of biomaterials to enhance the differentiation and regenerative capabilities of the cells. ${ }^{40}$ Exosomes are extracellular bilayer membrane vesicles that contain a diverse collection of proteins, lipids, and mRNAs/miRNAs and are secreted by a multitude of cell types. $4^{2}$ The exosomes secreted by iPSCs, ESCs, MSCs, and CDCs have different profiles,43,44 which ultimately physiologically manifest as increased self-renewal or expansion. Moreover, there is a growing body of evidence that exosome secretion is an important mode of cardiac cell communication..$^{21,22}$

\section{Route of Delivery}

Several factors contribute to the success of stem cell therapy. One of the most significant factors is the route of delivery 45,46 ; yet there is no consensus on the best route. There are four primary methods of administration that are clinically practical, and each has its own advantages and disadvantages (Figure 2). For instance, although intracoronary delivery may cause poor cell retention in the heart, it carries the benefit of minimal inflammation. 47 Transendocardial stem cell injections (TESI) are a minimally invasive technique where stem cells are injected directly into the myocardium through the endocardium. This procedure carries a small risk of perforation and arrhythmias; however, the retention of the cells is higher compared to other methods and in



Figure 2. Various Approaches for Stem Cell Delivery to the Heart.

A: Intravenous delivery (peripheral veins not shown). B: Transendocardial stem cell injection (TESI) via catheter. C: Epicardial injection. D: Intracoronary infusion via catheter. From Figure 10 of Golpanian et al. ${ }^{18}$ with permission of the American Physiological Society. 
certain pathologies has shown greater effectiveness. 45 Intravenous delivery of stem cells is the least invasive route and takes advantage of physiological attraction signals which induce cellular homing to the site of injury. $4^{8}$ With intravenous administration, there are concerns of poor implantation and retention. Unfortunately, very few studies have directly compared the therapeutic difference between routes of delivery.49 A meta-analysis of preclinical studies in models of acute myocardial infarction (AMI) by Kanelidis et al.45 concluded that TESI was associated with improved efficacy over intracoronary delivery. Additional preclinical and clinical studies are needed to establish an optimal route of delivery, and the most efficacious route may be celltype dependent.

\section{Acute Myocardial Infarction}

Bone-marrow derived mononuclear stem cells (BMMNCs) were some of the earliest cell types used in regenerative medicine to treat AMI.50,51 These cells are typically harvested from bone marrow and contain a heterogeneous group of cells including HSCs, MSCs, and EPCs. ${ }^{2}$ Because these cells can be obtained from bone marrow aspiration and do not require extensive expansion, BMMNCs are ideal for use in the setting of AMI and have been assessed in over 100 studies. 53 Clinical trials involving BMMNCs were first conducted in the setting of AMI.

One of the first clinical trials testing therapeutic efficacy of BMMNCs was TOPCARE-AMI (Transplantation of Progenitor Cells and Regeneration Enhancement in Acute Myocardial Infarction).54 This study evaluated BMMNCs delivered an average of 5 days after an AMI. The trial reported a significantly increased LVEF and reduced scar size. Two years later, the BOOST (Bone Marrow Transfer to Enhance ST-Elevation Infarct Regeneration) 55 trial showed similar promising results. It should be noted that the TOPCARE-AMI trial did not include a control group and the BOOST trial was open-label, since the control patients did not receive additional procedures, only standard care, compared to celltreated patients. Another trial, LEUVEN-AMI, also reported improved LVEF after BMMNC infusion therapy. ${ }^{6}$ The REPAIR-AMI (The Reinfusion of Enriched Progenitor Cells and Infarct Remodeling in Acute Myocardial Infarction) 57 trial is the largest phase III, double-blinded, placebo-controlled clinical trial to date and was conducted to assess the efficacy of BMMNCs. In this study, patients in the cell-treated arm had a significantly improved LVEF
(5.5\% in BMMNC group) compared to placebo (3.0\%). After 1 year, death, myocardial infarction (MI), and the need for revascularization were lower in the BMMNC group.

Although the initial studies were exciting, many subsequent studies demonstrated, at best, inconclusive results. The ASTAMI (the Autologous Stem-Cell Transplantation in Acute Myocardial Infarction) 58 trial, undertaken in 2006, demonstrated that after a 6-month follow-up, patients receiving cell treatment 6 days post-AMI showed no significant difference in LVEF or scar size compared to patients administered placebo. The multicenter, double-blinded, placebo-controlled TIME (Use of Adult Autologous Stem Cells in Treating People Who Have Had a Heart Attack) 59 and LateTIME (Use of Adult Autologous Stem Cells in Treating People 2 to 3 Weeks After Having a Heart Attack $)^{60}$ trials found no improvements in LVEF, left ventricular volumes, or wall motion as measured by cardiac magnetic resonance imaging between BMMNC and placebo groups. The SWISS AMI (Swiss Multicenter Intracoronary Stem Cells Study in Acute Myocardial Infarction) ${ }^{61}$ trial was a multicentered, open-labeled clinical trial that treated patients with BMMNCs either 5-7 days or 3-4 weeks after AMI. Neither group improved left ventricular function or scar size at 12 months; however, there was a high drop-out rate in this study. Finally, the repeat BOOST-2 trial ${ }^{62}$ was unable to replicate the results of the original study.

Preclinical data showed that a subpopulation of BMMNCs that were $\mathrm{CD} 34^{+}$could be a more suitable cell for AMI because of their angiogenic capacity. ${ }^{63}$ As such, the PreSERVE-AMI (NBS1o Versus Placebo Post ST Segment Elevation Myocardial Infarction) ${ }^{64}$ trial, the largest trial of stem cells for AMI in the United States, was conducted. This trial failed to show improvement in LVEF or resting myocardial perfusion; however, tertiary analyses demonstrated a significant association between change in LVEF and cell dose after adjusting for total ischemic time. ${ }^{64}$

The growing evidence of MSCs playing a key role in cardiac repair encouraged researchers to investigate their therapeutic efficacy in clinical trials. ${ }^{65}$ The effects of MSCs are the result of the secretion of cytokines, trophic factors, and matrix metalloproteinases which modulate the extracellular matrix and reduce infarct size and fibrosis. ${ }^{31}$ Compared to BMMNCs, human (h) MSCs are more efficacious in the setting of AMI. Hare et al. ${ }^{65}$ reported that precultured allogeneic hMSCs administered intrave- 
nously are safe, reduced episodes of ventricular tachycardia, and improved LVEF (6.7\% greater than baseline). Another trial, WJ-MSC-AMI (Intracoronary Human Wharton's Jelly-derived Mesenchymal Stem Cells Transfer in Patients with Acute Myocardial Infarction), ${ }^{66}$ demonstrated that MSCs derived from human umbilical cords increased LVEF $7.8 \% \pm$ $0.9 \%$ versus $2.8 \% \pm 1.2 \%$ ) and decreased end systolic volume (ESV) and end diastolic volume (EDV). There is also an ongoing trial, AMICI (Safety Study of Allogeneic Mesenchymal Precursor Cell Infusion in Myocardial Infarction), which is a phase II trial examining intracoronary delivery of mesenchymal precursor cells (NCTo1781390).

Allogeneic CSCs have also been tested for therapeutic efficacy in the phase I/II, randomized, doubleblind, placebo-controlled CAREMI trial (Cardiac Stem Cells in Patients with Acute Myocardial Infarction). ${ }^{67}$ Cardiac stem cells did not significantly improve scar size, left ventricular volumes, LVEF, or regional wall motion after 1 year of follow-up.

\section{CHRONIC ISCHEMIC CARDIOMYOPATHY}

Despite advances in interventional care for AMI, patients frequently go on to develop chronic ischemic cardiomyopathy (ICM). The growing evidence of efficacy of stem cell treatment in AMI inspired researchers to begin experiments and clinical trials investigating stem cell therapy in chronic ICM. A major paradigm of treatment for ICM is the attenuation of left ventricular enlargement. Compared to mainstream treatment, regenerative medicine seeks to restore normal function, potentially being curative rather than palliative. As ICM is a chronic condition, researchers can utilize and cultivate a variety of cell types in an effort to maximize therapeutic effects.

There are significantly fewer studies carried out with BMMNCs in the setting of ICM. The first study exploring the effects of BMMNCs on patients with ICM was carried out by Perin et al. ${ }^{68}$ In this prospective, non-randomized, open-labeled study, BMMNCs were delivered via TESI. An evaluation performed 4 months later concluded that LVEF significantly increased from a baseline of $20 \%$ to $29 \%$, which was accompanied by a reduction in ESV in treated patients. The TOPCARE-CHD (Transplantation of Progenitor Cells and Regeneration Enhancement in Chronic Postinfarction Heart Failure $)^{69}$ trial showed small but similarly significant increases in LVEF with BMMNC treatment that correlated with reductions in N-terminal pro-brain natriuretic peptide (NT-proBNP). However, cell treatment did not reduce scar size compared to placebo. Subsequent studies were not able to replicate the positive effects on LVEF. The FOCUS-CCTRN (First Mononuclear Cells Injected in the United States conducted by the Cardiovascular Cell Therapy Research Network)70 trial, a phase II, randomized double-blind, placebocontrolled study, showed no significant difference in LVEF or infarct size in patients treated with BMMNCs.

The TAC-HFT (The Transendocardial Autologous Cells [hMSC or hBMC] in Ischemic Heart Failure Trial) $)^{71}$ was one of the earliest trials examining MSCs as a treatment for ICM. Importantly, it was the first trial to compare BMMNCs to MSCs head-tohead. This phase II randomized, placebo-controlled study failed to demonstrate improvements in LVEF or left ventricular volumes; however, both groups showed improvement in quality of life (QoL) as measured by the Minnesota Living with Heart Failure Questionnaire (MLHFQ) score. Additionally, the 6-minute walk distance (6MWD) improved only in the MSC group. Infarct size was reduced by $19 \%$ in the MSC group, whereas in the BMMNC and placebo groups it remained unchanged. The POSEIDON trial (Percutaneous Stem Cell Injection Delivery Effects on Neomyogenesis) ${ }^{72}$ study compared allogeneic to autologous MSCs and demonstrated that both MSC groups reduced scar size by $\sim 33 \%$, consistent with the TAC-HF trial. Of note, both the POSEIDON and TAC-HFT studies showed that QoL can be improved without concomitant improvements in LVEF. The MSC-HF trial 73 assessed TESI of autologous MSCs and showed increased LVEF of $6.2 \%$ compared with placebo, as well as reduced left ventricular ESV. These increases were maintained at the 1-year follow-up while myocardial mass was greater than at 6 months. 74 There was a correlation between cell dose and improvements. 74 The randomized, double-blinded TRIDENT trial 75 examined dose-dependence of allogeneic MSCs. In this study, the 100 million cell dose improved absolute LVEF by $3.6 \%$ compared to no change in the 20 million cell dose group after 12 months. Additional, larger clinical trials are needed.

A more recent approach is treatment using combinations of stem cells, which may provide greater therapeutic efficacy than a single cells type, as was observed with MSCs+CSCs in preclinical studies in 
porcine models of ICM. ${ }^{76-78}$ These porcine studies formed the basis of the ongoing phase II CONCERTHF trial (Combination of Mesenchymal and C-kit ${ }^{+}$ Cardiac Stem Cells as Regenerative Therapy for Heart Failure), 79 which is assessing if the combination of MSCs plus CSCs provides greater cardiac repair in humans than either cell type alone. Other clinical ${ }^{80}$ and preclinical 77,81 studies have also demonstrated a positive effect of combination stem cell therapy.

Cardiospheres were first described after a population of cells isolated from subcultures of atrial or ventricular biopsy specimens were shown to be able to differentiate into cardiomyocytes, endothelial cells, and smooth muscle cells. 34 Cardiospheres contain a heterogeneous mixture of cell types including cells that express endothelial (KDR [human]/flk-1 [mouse], CD31), stem cell (CD34, c-kit, Sca-1), and mesenchymal (CD105, CD90) cell surface markers. ${ }^{34}$ However, the specific cell type contributing to cardiac functioning and remodeling is unknown. ${ }^{82}$ Promising preclinical work provided the basis for a phase I, randomized trial, CADUCEUS (CardiosphereDerived Autologous Stem Cells to Reverse Ventricular Dysfunction), ${ }^{83}$ in patients with ICM. At $1.5^{-3}$ months after MI, 17 patients were administered intracoronary injections of autologous CDCs ( $98 \%$ of cells given were $\mathrm{CD} 105$-positive). Although scar size was reduced by $42 \%$ in the treatment arm, CDC therapy failed to increase LVEF, reduce left ventricular volumes, or improve QoL as measured by MLHFQ. The ALLSTAR (Allogeneic Heart Stem Cells to Achieve Myocardial Regeneration) ${ }^{8} 4$ trial using CDCs had to be suspended by the Data Safety Monitoring Board because the study failed to meet the primary end point. Given the heterogeneous nature of this cell preparation, it may be difficult to identify which cell type(s) truly contributes to any beneficial effects.

Cardiopoietic stem cells (CPSCs) are MSCs that are manipulated ex vivo to undergo cardiopoiesis in order to enhance their cardio-reparative functionality. ${ }^{85,86}$ The randomized, double-blinded, placebocontrolled CHART-1 (Congestive Heart Failure Cardiopoietic Regenerative Therapy) ${ }^{87}$ trial was conducted to ascertain the safety and therapeutic value of CPSCs in patients with ICM. The primary efficacy end point of a Finkelstein-Schoenfeld hierarchical composite (mortality, worsening heart failure, MLHFQ, 6MWD, LVEF, ESV) at 39 weeks was not achieved.

\section{NON-ISCHEMIC DILATED CARDIOMYOPATHY}

Non-ischemic dilated cardiomyopathy (NIDCM) is the leading cause of death among heart transplant recipients. ${ }^{88}$ As with ICM, BMMNCs were the first cell type to be tested in the setting of NIDCM. In the TOPCARE-DCM (Transplantation of Progenitor Cells and Recovery of Left Ventricular Function in Patients with Non-Ischemic Dilatative Cardiomyopathy $)^{89}$ trial, patients showed improvements in LVEF, regional wall motion at 3 months after treatment, and decreased NT-proBNP levels at 1-year follow-up. Similarly, the ABCD (Autologous Bone Marrow Cells in Dilated Cardiomyopathy)9o trial found positive results, including QoL parameters, which conflicted with the MiHeart, ${ }^{11}$ a multicenter, randomized, double-blind clinical trial that evaluated intracoronary delivery of BMMNCs and showed no significant changes in LVEF and left ventricular volumes.

Compared to ICM, NIDCM has a more significant immunologic component. ${ }^{2}$ As such, MSC therapy could prove beneficial due to its immunomodulatory, reverse remodeling, and regenerative properties.93,94 The POSEIDON-DCM trial (Percutaneous Stem Cells Injection Delivery Effects on Neomyogenesis in Dilated Cardiomyopathy) 25 randomly allocated 37 patients with idiopathic NIDCM to receive TESI of allogeneic or autologous MSCs. Functional parameters and LVEF increased significantly only in the allogeneic group (Figure 3). Of note, LVEF increases were not accompanied by reductions in left ventricular volumes, suggesting that reverse remodeling is not the primary means by which cardiac function is improved. Incidence of major adverse cardiac events and hospitalization rate was also significantly lower in the allogeneic group. ${ }^{25}$ Moreover, treatment with allogenic MSCs significantly increased QoL and functional capacity. Both treatment arms noted significantly decreased systemic tumor necrosis factor (TNF)- $\alpha$ levels. The POSEIDON-DCM trial also demonstrated that patients lacking a pathologic genetic variant responded better to cell therapy (Figure 4). ${ }^{96}$ However, this study lacked a control group, and this approach should be further investigated in a larger study. A study by Vertelov et al. observed that ischemiatolerant MSCs, i.e. hMSCs cultured under hypoxic conditions, are more therapeutically efficacious than hMSCs grown in normoxia. ${ }^{97}$ To ascertain this effect 


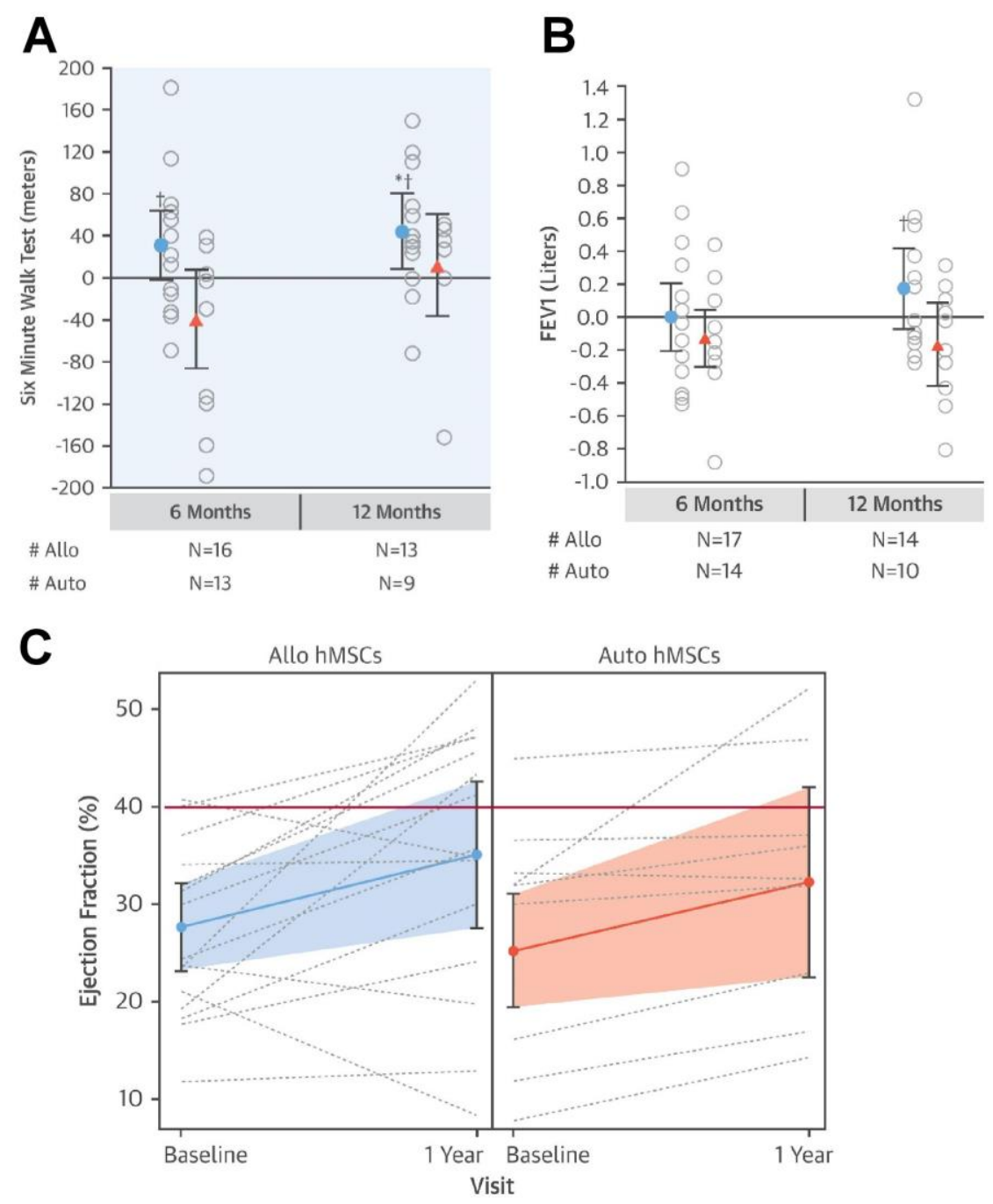

Figure 3. Differences in the Therapeutic Efficacy of Allogeneic hMSC and Autologous hMSC.

The POSEIDON-DCM ${ }^{95}$ study demonstrated differences in the therapeutic efficacy of allogeneic (Allo, blue) hMSC, and autologous (Auto, red) hMSC. A: Change from baseline in the 6-minute walk distance (6MWD). B: Change from baseline in forced expiratory volume in 1 second. C: Individual patient response in ejection fraction; shaded areas are $95 \% \mathrm{Cl}$. From Hare et al. ${ }^{95}$ [CC BY-NC-ND 4.0].

in vivo, Butler et al. ${ }^{8}$ conducted a pilot study in which bone marrow-derived MSCs isolated from healthy donors were grown under hypoxic conditions and subsequently administered to 22 patients. Although no improvements in left ventricle anatomy or function were noted, QoL and 6MWD scores improved significantly in the treatment arm.

Interestingly, the administration of $\mathrm{CD} 34^{+}$cells demonstrated consistent improvements in LVEF, 99 $6 \mathrm{MWD}$, brain natriuretic peptide (BNP) levels, as well as survival at 1 and 5 years post-treatment. 99
The comparison between intra-coronary and TESI delivery demonstrated that TESI produced higher engraftment and therapeutic efficacy. ${ }^{49}$ Importantly, a subset of patients with NIDCM and diabetes mellitus did not respond similarly to the non-diabetic population, which had an improvement in LVEF. ${ }^{100}$ These studies demonstrate that specific subpopulations of patients respond to a greater or lesser extent to the same therapy, illustrating the importance of adequately assessing the profile of patients, the cell(s) to be delivered, and the route of delivery. 


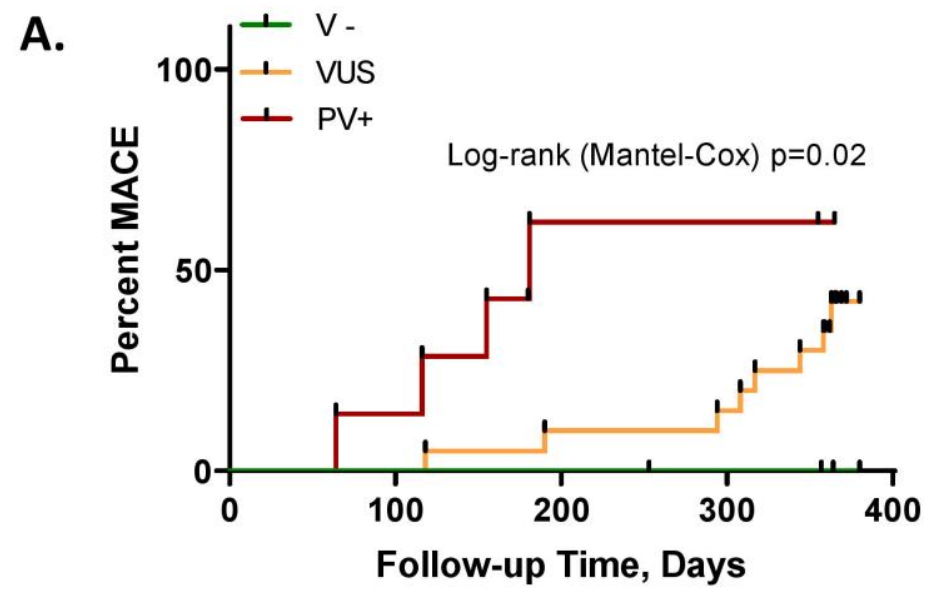

\begin{tabular}{|c|c|c|c|c|c|c|c|c|c|c|}
\hline \multicolumn{3}{|c|}{ Time (days) } & 50 & 100 & 150 & 200 & 250 & 300 & 350 & 400 \\
\hline \multirow{3}{*}{ 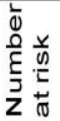 } & V. & 6 & 6 & 6 & 6 & 6 & 6 & 6 & 6 & 6 \\
\hline & VUS & 20 & 20 & 20 & 19 & 18 & 18 & 17 & 14 & 12 \\
\hline & $\mathrm{PV}+$ & 8 & 8 & 7 & 6 & 4 & 4 & 4 & 4 & 4 \\
\hline
\end{tabular}

B.



Figure 4. Genetic Variation Affects Major Adverse Clinical Events (MACE) and Survival in Response to Delivery of MSCs.

POSEIDON-DCM patients negative for pathologic genetic variants (V-, green) had fewer MACE (A) and greater survival (B) than patients with variants of uncertain significance (VUS, orange) or pathologic/likely pathologic variants (PV+, red). Overall, $P V+$ patients had a substantial increase in death, transplant, or left ventricular assist device (LVAD) risk by 1-year follow-up. From Figure 3, Rieger et al. ${ }^{96}$ [CC BY-NC-ND 4.0].

\section{OTHER POTENTIAL SOURCES OF CELLS FOR CARDIAC REPAIR}

\section{Pluripotent Stem Cells}

While many stem cells have been tested for their cardio-reparative capacity, ESCs and iPSCs have yet to be thoroughly assessed in clinical trials. As mentioned above, these cells have the greatest multi- lineage capability, but also some of the highest potential risks. ${ }^{37-39,101}$

\section{Embryonic Stem Cells}

Embryonic stem cells are immortal, pluripotent cells derived from the inner cell mass of the preimplantation embryo, that are propagated ex 
vivo. ${ }^{102,103}$ However, the risk of teratoma formation requires that these cells first undergo lineagedirected differentiation prior to transplantation. ${ }^{40,41}$ Additional concerns after transplantation are the risk of arrhythmias and rejection by the recipient.

Two preclinical studies involved the intramyocardial administration of human ESC-derived cardiomyocytes (hESC-CMs) into non-human primates following ischemia/reperfusion injury. ${ }^{11,13}$ Pigtail macaques were kept immunosuppressed and administered $1 \times 10^{9}$ hESC-CMs 2 weeks post-MI ${ }^{11}$ or $750 \times 10^{8}$ hESC-CMs 4 weeks post-MI. ${ }^{13}$ The hearts exhibited islands of engrafted hESC-CMs, but there was no reduction of infarct size, and non-lethal ventricular arrhythmias were seen in all animals. ${ }^{11,13} \mathrm{~A}$ similar study was conducted using $1 \times 10^{9} \mathrm{hESC}-\mathrm{CMs}$ in a porcine model of MI. Similar to the macaque studies, the immunosuppressed pigs had islands of engrafted hESC-CMs but no cardiac functional or structural improvements (Figure 5). ${ }^{14}$ These results suggest that further preclinical studies are needed to optimize the therapeutic effects of hESC-CMs. However, Menasche et al. demonstrated that hESCderived cardiac progenitor cells embedded into a fibrin scaffold are safe in a patient with severe heart failure. ${ }^{41}$ Cell therapy did not cause complications,
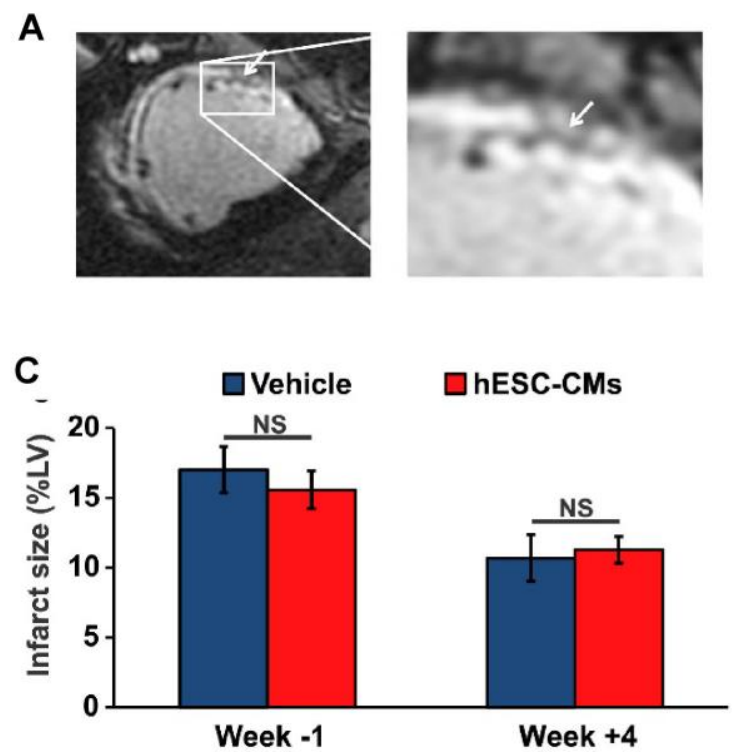

and after 3 months the patient showed improvements in cardiac function. Importantly, the European clinical study, ESCORT, in which hESCderived cardiac progenitors were transplanted within a fibrin patch into heart failure patients $(n=6)$, showed safety and efficacy. ${ }^{41}$ One patient died early post-operation from treatment-unrelated comorbidities. The other 5 patients showed no evidence of significant adverse effects (SAEs), and they improved symptomatically with an improved wall motion of the cell-treated segments.

\section{Induced Pluripotent Stem Cells}

Due to the ethical concerns of harvesting ESCs, scientists have sought alternative methods to isolate multipotent stem cells. Takahashi and Yamanaka developed a novel protocol to generate pluripotency from murine somatic cell by integrating a variety of transcription factors into the cell's genome via retroviral transduction. ${ }^{104}$ This technique was then applied to human somatic cells. ${ }^{105}$ Subsequent studies have demonstrated that these iPSCs have the capacity to differentiate into all three germ layers in addition to somatic cells, including cardiomyocytes and other cardiovascular cells. ${ }^{106,107}$ Furthermore, these cells could also aid in repair of heart valves and
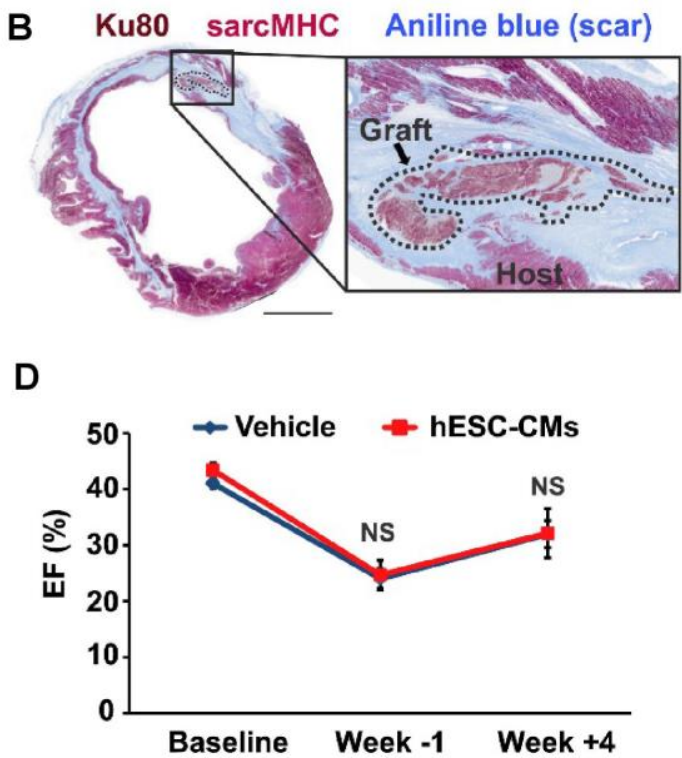

Figure 5. In a Porcine Model of MI, hESC-CMs Demonstrated Engraftment but no Functional or Structural Improvements.

Islands of engrafted cells were seen in immunosuppressed pigs receiving hESC-CMs by magnetic resonance imaging (A) and immunostaining (B). The hESC-CM-injected pigs demonstrate no reduction in scar size (C) or improvement in LVEF (D). Adapted from Romagnuolo et al. ${ }^{14}$ [CC BY 4.0]. 
vessels. ${ }^{108}$ A major concern when using these pluripotent cells, as with ESCs, is tumorigenesis. However, this risk can be mitigated by isolating cells or cell lines that have undergone at least some differentiation. ${ }^{109}$ An initial clinical trial to evaluate safety and efficacy of a patch with 100 million reprogrammed iPSC cardiomyocytes was approved in Japan. Three patients with ICM were treated initially; a further 7-10 patients will be recruited and followed up over the period of 1 year. ${ }^{110}$ The Treating Heart Failure With hPSC-CMs (HEAL-CHF) Trial (NCTo3763136) is an open-label study recruiting 5 patients to receive epicardial injection of allogeneic PSC-CMs. There are as yet no reports from either of these two studies. Continuing studies will have to investigate methods to maintain stable cell lines as well as address scalability for clinical grade production. ${ }^{111}$ Table 1 compares the efficacy of different cell types for increasing LVEF, and reducing EDV and scar size in clinical trials to date.

\section{Placental Stem Cells}

The placenta is a novel source of potentially cardioregenerative cells. Perinatal tissue is a rich source of a variety of stem cells that can be isolated from the amnion, chorion, umbilical cord (e.g. Wharton's jelly) and the placental cotyledons from the fetal side and the decidua from the maternal side. Many of these cells display MSC-like characteristics, such as adherence to plastic and immunomodulation. Furthermore, in vitro, they inhibit cardiomyocyte apoptosis and are pro-angiogenic (reviewed by Bollini et al. ${ }^{117}$ ).

Cells isolated from the murine near-term placenta and expressing the Caudal-type homeobox-2 (Cdx2) were recently reported to form beating cardiomyocytes and vascular lineages ex vivo. Furthermore, these $\mathrm{Cdx}_{2}{ }^{+}$cells homed to the injured heart and promoted cardiac repair when injected intravenously $\left(1 \times 10^{6}\right.$ cells $)$ post-MI in a mouse model. Three months post-injection, the cells were found integrated within the myocardium, primarily in the border zone, where they exhibited a cardiomyocyte morphology. Cell-treated hearts exhibited improved LVEF and stroke volume and reduced adverse remodeling compared to placebo-injected mice. ${ }^{118}$

\section{Tissue-specific MSCs}

Most studies have assessed the therapeutic effects of bone marrow- and adipose tissue-derived MSCs. These cells can be isolated and expanded in large

Table 1. Comparison of Cell Types.

\begin{tabular}{|c|c|c|c|c|c|c|c|c|c|c|c|c|c|}
\hline \multirow{3}{*}{$\begin{array}{l}\text { Cell } \\
\text { Type }\end{array}$} & \multirow{2}{*}{\multicolumn{2}{|c|}{$\begin{array}{l}\text { Preclinical } \\
\text { Animal } \\
\text { Studies }(n)\end{array}$}} & \multirow{2}{*}{\multicolumn{3}{|c|}{$\begin{array}{l}\text { Completed Clinical } \\
\text { Studies at } \\
\text { ClinicalTrials.gov ( } n)\end{array}$}} & \multicolumn{8}{|c|}{ Change in Clinical Data } \\
\hline & & & & & & \multicolumn{3}{|c|}{ LVEF (\%) } & \multicolumn{3}{|c|}{$\mathrm{EDV}(\mathrm{mL})$} & \multicolumn{2}{|c|}{$\begin{array}{c}\text { Change in Scar } \\
\text { Size (\%) }\end{array}$} \\
\hline & AMI & ICM & AMI & ICM & NIDCM & AMI & ICM & NIDCM & AMI & ICM & NIDCM & AMI & ICM \\
\hline MSCs & 335 & 133 & $4^{*}$ & $6^{\dagger}$ & $2 \neq$ & 6.0 & 5.7 & 8.0 & $\mathrm{~N} / \mathrm{A}$ & -9.3 & N/A & -6.2 & -25.9 \\
\hline CPCs & 182 & 87 & 0 & $1^{\S}$ & 0 & $\mathrm{~N} / \mathrm{A}$ & 5.4 & N/A & $\mathrm{N} / \mathrm{A}$ & -12 & N/A & N/A & -12 \\
\hline ESCs & 3 & 0 & 0 & 1 ** & 0 & $\mathrm{~N} / \mathrm{A}$ & 12.5 & N/A & $\mathrm{N} / \mathrm{A}$ & -14.5 & N/A & N/A & $\mathrm{N} / \mathrm{A}$ \\
\hline iPSCs & 3 & 0 & 0 & 0 & 0 & $\mathrm{~N} / \mathrm{A}$ & $\mathrm{N} / \mathrm{A}$ & $\mathrm{N} / \mathrm{A}$ & $\mathrm{N} / \mathrm{A}$ & $\mathrm{N} / \mathrm{A}$ & N/A & N/A & $\mathrm{N} / \mathrm{A}$ \\
\hline
\end{tabular}

* References 65, 66, 112, and 113.

† References 71-74, 75, 114, and 115.

‡ References 25 and 98

§ Reference 116.

** Reference 41. Cells delivered via patch not intramyocardial.

Initial search criteria: Heart or cardiac, cells, completed studies, with results $(=148$ results on clinicaltrials.gov). An advanced search of these results was performed for "acute myocardial infarction," "ischemic cardiomyopathy," or "non-ischemic dilated cardiomyopathy," each with the intervention of: "mesenchymal stem cells" for MSCs; "cardiosphere-derived stem cells" and "cardiopoietic stem cells" for CPCs; "embryonic stem cells" for ESCs; or "induced pluripotent stem cells" for iPSCs.

$\mathrm{N} / \mathrm{A}$, data not available. 
quantities while retaining their immunomodulatory characteristics, ${ }^{119}$ but the properties of these MSCs are influenced by their tissue of origin. For example, bone marrow-derived MSCs are highly proangiogenic $^{120}$ and may be more immunosuppressive than adipose-derived MSCs. ${ }^{121,122}$ Mesenchymal stem cells have also been isolated from other tissues, including umbilical cord (Wharton's jelly), amniotic fluid, peripheral blood, and the heart. Again, the tissue of origin appears to provide MSCs with characteristic properties ${ }^{122-126}$ and secretomes, ${ }^{127}$ and for therapeutic use it may be important to determine which MSC source is best for a specific patient.

\section{EXOSOMES/MICROVESICLES}

Some studies suggest that exosomes have an (almost) equivalent therapeutic efficacy as intact cells. ${ }^{128-130}$ Other data also demonstrate that the therapeutic effect of cell therapy may not correlate with engraftment, ${ }^{131}$ supporting a paracrine mechanism. The discovery of these paracrine mechanisms of repair not only significantly challenges the notion of engraftment-dependent healing, but also opens another avenue of therapy delivery.42,132 Engineered exosomes with an ischemic myocardium-targeting peptide can enhance myocardial viability and reduce infarct size after MI in mouse models. ${ }^{33,133-135}$ Cellfree suspensions containing important reparative exosomes could be used instead of intact cells, avoiding some of the inherent issues associated with cells, such as ex vivo expansion, tumor formation, and immune rejection. Studies directly comparing the different approaches will provide guidance toward the most therapeutic approach.

\section{PATCHES/BIOMATERIALS: BIO- ENGINEERING IN STEM CELL THERAPY}

Transplantation of viable cells into the harsh environment of necrotic myocardium remains a significant therapeutic challenge resulting in very poor cell retention. ${ }^{136,137}$ To combat this problem, tissue engineering approaches have designed biomaterials as cell retention mediums. These injectable biomaterials must perform many (often contradictory) functions. They must be biodegradable, biocompatible, provide mechanical support, be of appropriate dimension, allow for precise placement, ${ }^{138}$ improve cell survival, and promote tissue regeneration. ${ }^{139,140}$ These polymers can either be synthetic or naturally derived, each having their own advantages and disadvantages. Some polymers can even be specifi- cally tailored to optimize cardiac repair, ${ }^{141}$ and $3 \mathrm{D}$ printing has increased the available types of biomaterials, improving cell integration and vascularization. ${ }^{142}$ Preclinical studies have demonstrated improved cell viability and cardiac repair when used with human pluripotent stem cells and MSCs. ${ }^{141,143,144}$ While significant progress has been made, improving polymer compatibility and mechanical properties must occur before clinical studies can begin.

\section{FUTURE DIRECTIONS}

Stem cell and cell-based therapy is still relatively new, and studies need to define the cell type/cell product, the frequency and route of stem cell injection, and the patient population most likely to respond. Recent preclinical studies show that the administration of a large number of exosomes often produces similar cardiac repair as cell injection, ${ }^{145,146}$ prompting the view that the cells are not needed. However, this equivalency is often dependent on the route of exosome administration and has only been demonstrated in the short term, while stem cell therapy has demonstrated long-term effects, despite poor stem cell retention and survival. Studies comparing the long-term effects of cells versus exosomes (or combination of the two) still need to be performed.

Other approaches toward optimizing stem cell therapy include assessing the effects of multiple rounds of injections. Tokita et al. demonstrated that three rounds of cardiac progenitor cell injections provided greater cardiac repair than a single injection of 3-fold more cells in a mouse model of ischemia. ${ }^{147}$ As mentioned above, the administration of a combination of stem cells is therapeutically synergistic, providing greater benefits than the individual cells in swine models of ICM,74-76 and this approach forms the basis of the CONCERT-HF clinical trial.77

Additionally, the choice of patient is important. While the CHART-1 study did not meet its primary end point, a subpopulation of patients responded well. 36,85 Precision medicine approaches may also influence a patient's responsiveness to stem cell therapy. As mentioned above, Rieger et al. recently showed that, in the POSEIDON-DCM trial, patients who did not have a specific genetic variant responded better to treatment. ${ }^{6}$ Furthermore, sex, ${ }^{148}$ age, ${ }^{149}$ and serum concentration of a variety of factors ${ }^{150}$ may play significant roles in a patient's response and need to be taken into account when designing clinical trials (Figure 6). 




Figure 6. Effectiveness of MSCs Is Independent of Sex of the Patient.

Cell therapy improves cardiac function, functional parameters, endothelial function, and inflammatory response independently of the sex of the patient.

LVEF, left ventricular ejection fraction; MLHFQ, Minnesota Living with Heart Failure Questionnaire; NYHA Class, New York Heart Association Functional Classification.

Adapted from the graphical abstract in Florea et al. ${ }^{148}$; by permission of Oxford University Press.

Clinical trials will also need to be nimble and develop better ways to assess efficacy and increase study power by incorporating ongoing results as well as new information that becomes available after the trial commences. The DREAM-HF (Double-Blind Randomized Assessment of Clinical Events With Allogeneic Mesenchymal Precursor Cells in Advanced Heart Failure; NCTo2032004) is such a trial. It is a phase III, randomized, placebo-controlled study assessing the safety and efficacy of mesenchymal precursor cells (MPCs) as immunotherapy in patients with advanced, chronic heart failure with reduced ejection fraction. The DREAM-HF trial uses patient enrichment strategies to establish a patient population with reduced heterogeneity (baseline disease enrichment), high targeted outcome event rate (prognostic enrichment) and higher likelihood to respond (predictive enrichment). Adaptive statistical models are also needed. The DREAM-HF trial uses a joint frailty model, which treats terminal and recurrent heart failure events differently and models correlations between recur- rent and terminal events, which takes into account random, between-patient differences. Such innovative approaches will allow for smaller, yet more definitive trial designs. ${ }^{151}$ Along with CONCERT-HF, DREAM-HF is likely to report results in 2020, and together these trials will add substantially to the clinical and mechanistic data base of the potential of cell-based therapy for chronic heart failure.

\section{CONCLUSION}

The past two decades have witnessed substantial translational efforts to develop cell-based therapies for heart disease. While many clinical trials have been conducted, testing several strategies, the field has yet to yield a clear understanding of the clinical application in this important area. Nonetheless, the studies conducted to date have laid a robust groundwork for ongoing new efforts-including phase III and larger-powered phase II studies, as well as major progress at the bench and in preclinical models in the application of pluripotent stem cells. With these ongoing avenues of research, the field is 
moving closer to yielding a successful strategy for addressing one of the largest unmet needs in modern medicine, that of chronic heart disease.

\section{REFERENCES}

1. Virani SS, Alonso A, Benjamin EJ, et al. Heart disease and stroke statistics-2020 update: a report from the American Heart Association. Circulation 2020;141: e139-596. CrossRef

2. Sorabella RA, Guglielmetti L, Kantor A, et al. Cardiac donor risk factors predictive of short-term heart transplant recipient mortality: an analysis of the United Network for Organ Sharing database. Transplant Proc 2015;47:2944-51. CrossRef

3. Murry CE, MacLellan WR. Stem cells and the heartthe road ahead. Science 2020;367:854-5. CrossRef

4. Lázár E, Sadek HA, Bergmann O. Cardiomyocyte renewal in the human heart: insights from the fallout. Eur Heart J 2017;38:2333-42. CrossRef

5. Kalra DK, Zhu X, Ramchandani MK, et al. Increased myocardial gene expression of tumor necrosis factoralpha and nitric oxide synthase-2: a potential mechanism for depressed myocardial function in hibernating myocardium in humans. Circulation 2002;105: 1537-40. $\underline{\text { CrossRef }}$

6. Asahara T, Masuda H, Takahashi T, et al. Bone marrow origin of endothelial progenitor cells responsible for postnatal vasculogenesis in physiological and pathological neovascularization. Cir Res 1999;85: 221-8. CrossRef

7. Kandalam V, Basu R, Moore L, et al. Lack of tissue inhibitor of metalloproteinases 2 leads to exacerbated left ventricular dysfunction and adverse extracellular matrix remodeling in response to biomechanical stress. Circulation 2011;124:2094-105. CrossRef

8. Kubo SH, Rector TS, Bank AJ, Williams RE, Heifetz SM. Endothelium-dependent vasodilation is attenuated in patients with heart failure. Circulation 1991; 84:1589-96. CrossRef

9. Roura S, Planas F, Prat-Vidal C, et al. Idiopathic dilated cardiomyopathy exhibits defective vascularization and vessel formation. Eur J Heart Fail 2007; 9:995-1002. $\underline{\text { CrossRef }}$

10. Madonna R, Van Laake LW, Davidson SM, et al. Position paper of the European Society of Cardiology Working Group Cellular Biology of the Heart: cellbased therapies for myocardial repair and regeneration in ischemic heart disease and heart failure. Eur Heart J 2016;37:1789-98. $\underline{\text { CrossRef }}$

11. Chong JJ, Yang X, Don CW, et al. Human embryonicstem-cell-derived cardiomyocytes regenerate nonhuman primate hearts. Nature 2014;510:273-7. CrossRef
12. Laflamme MA, Murry CE. Heart regeneration. Nature 2011;473:326-35. CrossRef

13. Liu YW, Chen B, Yang X, et al. Human embryonic stem cell-derived cardiomyocytes restore function in infarcted hearts of non-human primates. Nat Biotechnol 2018;36:597-605. CrossRef

14. Romagnuolo R, Masoudpour H, Porta-Sanchez A, et al. Human embryonic stem cell-derived cardiomyocytes regenerate the infarcted pig heart but induce ventricular tachyarrhythmias. Stem Cell Reports 2019;12:967-81. $\underline{\text { CrossRef }}$

15. Fisher SA, Doree C, Mathur A, Taggart DP, MartinRendon E. Stem cell therapy for chronic ischaemic heart disease and congestive heart failure. Cochrane Database Syst Rev 2016;12:CDo07888. CrossRef

16. Fisher SA, Zhang H, Doree C, Mathur A, MartinRendon E. Stem cell treatment for acute myocardial infarction. Cochrane Database Syst Rev 2015;(9): CDoo6536. CrossRef

17. Afzal MR, Samanta A, Shah ZI, et al. Adult bone marrow cell therapy for ischemic heart disease: evidence and insights from randomized controlled trials. Circ Res 2015;117:558-75.

18. Golpanian S, Wolf A, Hatzistergos KE, Hare JM. Rebuilding the damaged heart: mesenchymal stem cells, cell-based therapy, and engineered heart tissue. Physiol Rev 2016;96:1127-68. CrossRef

19. Nguyen PK, Rhee J-W, Wu JC. Adult stem cell therapy and heart failure, 2000 to 2016: a systematic review. JAMA Cardiol 2016;1:831-41. CrossRef

20. Tompkins BA, Balkan W, Winkler J, et al. Preclinical studies of stem cell therapy for heart disease. Circ Res 2018;122:1006-20. $\underline{\text { CrossRef }}$

21. Gnecchi M, He H, Liang OD, et al. Paracrine action accounts for marked protection of ischemic heart by Akt-modified mesenchymal stem cells. Nat Med 2005;11:367-8. CrossRef

22. Sluijter JP, Verhage V, Deddens JC, van den Akker F, Doevendans PA. Microvesicles and exosomes for intracardiac communication. Cardiovasc Res 2014; 102:302-11. CrossRef

23. Iaconetti C, Sorrentino S, De Rosa S, Indolfi C. Exosomal miRNAs in heart disease. Physiology (Bethesda) 2015;31:16-24. $\underline{\text { CrossRef }}$

24. Mayourian J, Cashman TJ, Ceholski DK, et al. Experimental and computational insight into human mesenchymal stem cell paracrine signaling and heterocellular coupling effects on cardiac contractility and arrhythmogenicity. Circ Res 2017;121:411-23. CrossRef

25. Hare JM, DiFede DL, Rieger AC, et al. Randomized comparison of allogeneic versus autologous mesenchymal stem cells for nonischemic dilated cardiomy- 
opathy: POSEIDON-DCM Trial. J Am Coll Cardiol 2017;69:526-37. CrossRef

26. Sanganalmath SK, Bolli R. Cell therapy for heart failure: a comprehensive overview of experimental and clinical studies, current challenges, and future directions. Circ Res 2013;113:810-34. CrossRef

27. Williams AR, Hare JM. Mesenchymal stem cells: biology, pathophysiology, translational findings, and therapeutic implications for cardiac disease. Circ Res 2011;109:923-40. CrossRef

28. Golpanian S, Schulman IH, Ebert RF, et al. Concise review: review and perspective of cell dosage and routes of administration from preclinical and clinical studies of stem cell therapy for heart disease. Stem Cells Transl Med 2016;5:186-91. CrossRef

29. Gnecchi M, Zhang Z, Ni A, Dzau VJ. Paracrine mechanisms in adult stem cell signaling and therapy. Circ Res 2008;103:1204-19. CrossRef

30. Hatzistergos KE, Quevedo H, Oskouei BN, et al. Bone marrow mesenchymal stem cells stimulate cardiac stem cell proliferation and differentiation. Circ Res 2010;107:913-22. CrossRef

31. Mirotsou M, Jayawardena TM, Schmeckpeper J, Gnecchi M, Dzau VJ. Paracrine mechanisms of stem cell reparative and regenerative actions in the heart. J Mol Cell Cardiol 2011;50:280-9. CrossRef

32. Hill JM, Zalos G, Halcox JP, et al. Circulating endothelial progenitor cells, vascular function, and cardiovascular risk. N Engl J Med 2003;348:593-600. CrossRef

33. Bearzi C, Rota M, Hosoda T, et al. Human cardiac stem cells. Proc Natl Acad Sci U S A 2007; 104:14068-73. CrossRef

34. Messina E, De Angelis L, Frati G, et al. Isolation and expansion of adult cardiac stem cells from human and murine heart. Circ Res 2004;95:911-21. CrossRef

35. Li TS, Cheng K, Malliaras K, et al. Direct comparison of different stem cell types and subpopulations reveals superior paracrine potency and myocardial repair efficacy with cardiosphere-derived cells. J Am Coll Cardiol 2012;59:942-53. CrossRef

36. Bartunek J, Davison B, Sherman W, et al. Congestive Heart Failure Cardiopoietic Regenerative Therapy (CHART-1) trial design. Eur J Heart Fail 2016;18: 160-8. $\underline{\text { CrossRef }}$

37. Takahashi K, Tanabe K, Ohnuki M, et al. Induction of pluripotent stem cells from adult human fibroblasts by defined factors. Cell 2007;131:861-72.

38. Yang X, Pabon L, Murry CE. Engineering adolescence: maturation of human pluripotent stem cellderived cardiomyocytes. Circ Res 2014;114:511-23. $\underline{\text { CrossRef }}$
39. Gepstein L. Derivation and potential applications of human embryonic stem cells. Circ Res 2002;91:86676. CrossRef

40. Cambria E, Pasqualini FS, Wolint P, et al. Translational cardiac stem cell therapy: advancing from firstgeneration to next-generation cell types. NPJ Regen Med 2017;2:17. CrossRef

41. Menasche P, Vanneaux V, Hagege A, et al. Transplantation of human embryonic stem cell-derived cardiovascular progenitors for severe ischemic left ventricular dysfunction. J Am Coll Cardiol 2018; 71:429-38. $\underline{\text { CrossRef }}$

42. Sahoo S, Losordo DW. Exosomes and cardiac repair after myocardial infarction. Circ Res 2014;114:33344. $\underline{\text { CrossRef }}$

43. Wang Y, Zhang L, Li Y, et al. Exosomes/microvesicles from induced pluripotent stem cells deliver cardioprotective miRNAs and prevent cardiomyocyte apoptosis in the ischemic myocardium. Int J Cardiol 2015; 192:61-9. CrossRef

44. Han C, Sun X, Liu L, et al. Exosomes and their therapeutic potentials of stem cells. Stem Cells Int 2016; 2016:7653489. CrossRef

45. Kanelidis AJ, Premer C, Lopez J, Balkan W, Hare JM. Route of delivery modulates the efficacy of mesenchymal stem cell therapy for myocardial infarction: a meta-analysis of preclinical studies and clinical trials. Circ Res 2017;120:1139-50. CrossRef

46. Kawamura M, Miyagawa S, Fukushima S, et al. Enhanced survival of transplanted human induced pluripotent stem cell-derived cardiomyocytes by the combination of cell sheets with the pedicled omental flap technique in a porcine heart. Circulation 2013; 128(11 Suppl 1):S87-94. CrossRef

47. Poynter JA, Herrmann JL, Manukyan MC, et al. Intracoronary mesenchymal stem cells promote postischemic myocardial functional recovery, decrease inflammation, and reduce apoptosis via a signal transducer and activator of transcription 3 mechanism. $J$ Am Coll Surg 2011;213:253-60. CrossRef

48. Rasmussen JG, Frobert O, Holst-Hansen C, et al. Comparison of human adipose-derived stem cells and bone marrow-derived stem cells in a myocardial infarction model. Cell Transplant 2014;23:195-206. CrossRef

49. Vrtovec B, Poglajen G, Lezaic L, et al. Comparison of transendocardial and intracoronary $\mathrm{CD}_{34}+$ cell transplantation in patients with nonischemic dilated cardiomyopathy. Circulation 2013;128(11 Suppl 1): S42-9. CrossRef

50. Ferrari G, Cusella-De Angelis G, Coletta M, et al. Muscle regeneration by bone marrow-derived myogenic progenitors. Science 1998;279:1528-30. CrossRef 
51. Orlic D, Kajstura J, Chimenti S, et al. Bone marrow cells regenerate infarcted myocardium. Nature 2001; 410:701-5. CrossRef

52. Astori G, Soncin S, Lo Cicero V, et al. Bone marrow derived stem cells in regenerative medicine as advanced therapy medicinal products. Am J Transl Res 2010;2:285-95.

53. Allan R, Kass M, Glover C, Haddad H. Cellular transplantation: future therapeutic options. Curr Opin Cardiol 2007;22:104-10. CrossRef

54. Schachinger V, Assmus B, Britten MB, et al. Transplantation of progenitor cells and regeneration enhancement in acute myocardial infarction: final oneyear results of the TOPCARE-AMI Trial. J Am Coll Cardiol 2004;44:1690-9. CrossRef

55. Meyer GP, Wollert KC, Lotz J, et al. Intracoronary bone marrow cell transfer after myocardial infarction: 5-year follow-up from the randomized-controlled BOOST trial. Eur Heart J 2009;30:2978-84. CrossRef

56. Janssens S, Dubois C, Bogaert J, et al. Autologous bone marrow-derived stem-cell transfer in patients with ST-segment elevation myocardial infarction: double-blind, randomised controlled trial. Lancet 2006;367:113-21. $\underline{\text { CrossRef }}$

57. Schachinger V, Erbs S, Elsasser A, et al. Improved clinical outcome after intracoronary administration of bone-marrow-derived progenitor cells in acute myocardial infarction: final 1-year results of the REPAIRAMI trial. Eur Heart J 2006;27:2775-83. CrossRef

58. Lunde K, Solheim S, Aakhus S, Arnesen H, Abdelnoor $\mathrm{M}$, Forfang K. Autologous stem cell transplantation in acute myocardial infarction: the ASTAMI randomized controlled trial. Intracoronary transplantation of autologous mononuclear bone marrow cells, study design and safety aspects. Scand Cardiovasc J 2005; 39:150-8. CrossRef

59. Traverse JH, Henry TD, Pepine CJ, et al. TIME trial: effect of timing of stem cell delivery following STelevation myocardial infarction on the recovery of global and regional left ventricular function: final 2year analysis. Circ Res 2018;122:479-88. CrossRef

6o. Traverse JH, Henry TD, Vaughan DE, et al. LateTIME: a phase-II, randomized, double-blinded, placebo-controlled, pilot trial evaluating the safety and effect of administration of bone marrow mononuclear cells 2 to 3 weeks after acute myocardial infarction. Tex Heart Inst J 2010;37:412-20.

61. Surder D, Schwitter J, Moccetti T, et al. Cell-based therapy for myocardial repair in patients with acute myocardial infarction: rationale and study design of the SWiss multicenter Intracoronary Stem cells Study in Acute Myocardial Infarction (SWISS-AMI). Am Heart J 2010;160:58-64. $\underline{\text { CrossRef }}$
62. Wollert KC, Meyer GP, Muller-Ehmsen J, et al. Intracoronary autologous bone marrow cell transfer after myocardial infarction: the BOOST-2 randomised placebo-controlled clinical trial. Eur Heart $\mathrm{J}$ 2017;38:2936-43. $\underline{\text { CrossRef }}$

63. Chong MS, Ng WK, Chan JK. Concise review: endothelial progenitor cells in regenerative medicine: applications and challenges. Stem Cells Transl Med 2016;5:530-8. CrossRef

64. Quyyumi AA, Vasquez A, Kereiakes DJ, et al. PreSERVE-AMI: a randomized, double-blind, placebocontrolled clinical trial of intracoronary administration of autologous CD34+ cells in patients with left ventricular dysfunction post STEMI. Circ Res 2017; 120:324-31. CrossRef

65. Hare JM, Traverse JH, Henry TD, et al. A randomized, double-blind, placebo-controlled, dose-escalation study of intravenous adult human mesenchymal stem cells (prochymal) after acute myocardial infarction. $\mathrm{J}$ Am Coll Cardiol 2009;54:2277-86. CrossRef

66. Gao LR, Chen Y, Zhang NK, et al. Intracoronary infusion of Wharton's jelly-derived mesenchymal stem cells in acute myocardial infarction: double-blind, randomized controlled trial. BMC Med 2015;13:162. CrossRef

67. Fernandez-Aviles F, Sanz-Ruiz R, Bogaert J, et al. Safety and efficacy of intracoronary infusion of allogeneic human cardiac stem cells in patients with STsegment elevation myocardial infarction and left ventricular dysfunction. Circ Res 2018;123:579-89. CrossRef

68. Perin EC, Dohmann HF, Borojevic R, et al. Transendocardial, autologous bone marrow cell transplantation for severe, chronic ischemic heart failure. Circulation 2003;107:2294-302.

69. Assmus B, Fischer-Rasokat U, Honold J, et al. Transcoronary transplantation of functionally competent BMCs is associated with a decrease in natriuretic peptide serum levels and improved survival of patients with chronic postinfarction heart failure: results of the TOPCARE-CHD Registry. Circ Res 2007; 100:1234-41. $\underline{\text { CrossRef }}$

70. Perin EC, Willerson JT, Pepine CJ, et al. Effect of transendocardial delivery of autologous bone marrow mononuclear cells on functional capacity, left ventricular function, and perfusion in chronic heart failure: the FOCUS-CCTRN trial. JAMA 2012;307:171726. $\underline{\text { CrossRef }}$

71. Heldman AW, DiFede DL, Fishman JE, et al. Transendocardial mesenchymal stem cells and mononuclear bone marrow cells for ischemic cardiomyopathy: the TAC-HFT randomized trial. JAMA 2014; 311:62-73. $\underline{\text { CrossRef }}$ 
72. Hare JM, Fishman JE, Gerstenblith G, et al. Comparison of allogeneic vs autologous bone marrow-derived mesenchymal stem cells delivered by transendocardial injection in patients with ischemic cardiomyopathy: the POSEIDON randomized trial. JAMA 2012;308:2369-79. CrossRef

73. Mathiasen AB, Qayyum AA, Jorgensen E, et al. Bone marrow-derived mesenchymal stromal cell treatment in patients with severe ischaemic heart failure: a randomized placebo-controlled trial (MSC-HF trial). Eur Heart J 2015;36:1744-53. CrossRef

74. Mathiasen AB, Qayyum AA, Jørgensen E, et al. Bone marrow-derived mesenchymal stromal cell treatment in patients with ischaemic heart failure: final 4-year follow-up of the MSC-HF trial. Eur J Heart Fail 2019 Dec 21. [Epub ahead of print] CrossRef

75. Florea V, Rieger AC, DiFede DL, et al. Dose comparison study of allogeneic mesenchymal stem cells in patients with ischemic cardiomyopathy (The TRIDENT Study). Circ Res 2017;121:1279-90. CrossRef

76. Karantalis V, Suncion-Loescher VY, Bagno L, et al. Synergistic effects of combined cell therapy for chronic ischemic cardiomyopathy. J Am Coll Cardiol 2015;66:1990-9. $\underline{\text { CrossRef }}$

77. Natsumeda M, Florea V, Rieger AC, et al. A combination of allogeneic stem cells promotes cardiac regeneration. J Am Coll Cardiol 2017;70:2504-15.

78. Williams AR, Hatzistergos KE, Addicott B, et al. Enhanced effect of combining human cardiac stem cells and bone marrow mesenchymal stem cells to reduce infarct size and to restore cardiac function after myocardial infarction. Circulation 2013;127:213-23. CrossRef

79. Bolli R, Hare JM, March KL, et al. Rationale and design of the CONCERT-HF trial (combination of mesenchymal and c-kit(+) cardiac stem cells as regenerative therapy for heart failure). Circ Res 2018;122: 1703-15. CrossRef

8o. Patel AN, Henry TD, Quyyumi AA, et al. Ixmyelocel-T for patients with ischaemic heart failure: a prospective randomised double-blind trial. Lancet 2016;387: 2412-21. CrossRef

81. Puymirat E, Geha R, Tomescot A, et al. Can mesenchymal stem cells induce tolerance to cotransplanted human embryonic stem cells? Mol Ther 2009;17:17682. CrossRef

82. Ashur C, Frishman WH. Cardiosphere-derived cells and ischemic heart failure. Cardiol Rev 2018;26:821. $\underline{\text { CrossRef }}$

83. Makkar RR, Smith RR, Cheng K, et al. Intracoronary cardiosphere-derived cells for heart regeneration after myocardial infarction (CADUCEUS): a prospective, randomised phase 1 trial. Lancet 2012;379:895-904. CrossRef

84. Chakravarty T, Makkar RR, Ascheim DD, et al. ALLogeneic Heart STem Cells to Achieve Myocardial Regeneration (ALLSTAR) trial: rationale and design. Cell Transplant 2017;26:205-14. CrossRef

85. Behfar A, Yamada S, Crespo-Diaz R, et al. Guided cardiopoiesis enhances therapeutic benefit of bone marrow human mesenchymal stem cells in chronic myocardial infarction. J Am Coll Cardiol 2010;56: 721-34. CrossRef

86. Bartunek J, Behfar A, Dolatabadi D, et al. Cardiopoietic stem cell therapy in heart failure: the C-CURE (Cardiopoietic stem Cell therapy in heart failURE) multicenter randomized trial with lineage-specified biologics. J Am Coll Cardiol 2013;61:2329-38. CrossRef

87. Bartunek J, Terzic A, Davison BA, et al. Cardiopoietic cell therapy for advanced ischaemic heart failure: results at 39 weeks of the prospective, randomized, double blind, sham-controlled CHART-1 clinical trial. Eur Heart J 2017;38:648-60. $\underline{\text { CrossRef }}$

88. Lund LH, Khush KK, Cherikh WS, et al. The registry of the international society for heart and lung transplantation: thirty-fourth adult heart transplantation report-2017; focus theme: allograft ischemic time. $\mathrm{J}$ Heart Lung Transplant 2017;36:1037-46. CrossRef

89. Fischer-Rasokat U, Assmus B, Seeger FH, et al. A pilot trial to assess potential effects of selective intracoronary bone marrow-derived progenitor cell infusion in patients with nonischemic dilated cardiomyopathy: final 1-year results of the transplantation of progenitor cells and functional regeneration enhancement pilot trial in patients with nonischemic dilated cardiomyopathy. Circ Heart Fail 2009;2:417-23. CrossRef

90. Seth S, Bhargava B, Narang R, et al. The ABCD (Autologous Bone Marrow Cells in Dilated Cardiomyopathy) trial a long-term follow-up study. J Am Coll Cardiol 2010;55:1643-4. CrossRef

91. Martino H, Brofman P, Greco O, et al. Multicentre, randomized, double-blind trial of intracoronary autologous mononuclear bone marrow cell injection in non-ischaemic dilated cardiomyopathy (the dilated cardiomyopathy arm of the MiHeart study). Eur Heart J 2015;36:2898-904. CrossRef

92. Bello D, Shah DJ, Farah GM, et al. Gadolinium cardiovascular magnetic resonance predicts reversible myocardial dysfunction and remodeling in patients with heart failure undergoing beta-blocker therapy. Circulation 2003;108:1945-53. CrossRef 
93. Nahrendorf M, Frantz S, Swirski FK, et al. Imaging systemic inflammatory networks in ischemic heart disease. J Am Coll Cardiol 2015;65:1583-91. CrossRef

94. Seropian IM, Toldo S, Van Tassell BW, Abbate A. Antiinflammatory strategies for ventricular remodeling following ST-segment elevation acute myocardial infarction. J Am Coll Cardiol 2014;63:1593-603. CrossRef

95. Banerjee MN, Bolli R, Hare JM. Clinical studies of cell therapy in cardiovascular medicine: recent developments and future directions. Circ Res 2018;123: 266-87. CrossRef

96. Rieger AC, Myerburg RJ, Florea V, et al. Genetic determinants of responsiveness to mesenchymal stem cell injections in non-ischemic dilated cardiomyopathy. EBioMedicine 2019;48:377-85. CrossRef

97. Vertelov G, Kharazi L, Muralidhar MG, Sanati G, Tankovich T, Kharazi A. High targeted migration of human mesenchymal stem cells grown in hypoxia is associated with enhanced activation of RhoA. Stem Cell Res Ther 2013;4:5.

98. Butler J, Epstein SE, Greene SJ, et al. Intravenous allogeneic mesenchymal stem cells for nonischemic cardiomyopathy: safety and efficacy results of a phase II-A randomized trial. Circ Res 2017;120:332-40. CrossRef

99. Vrtovec B, Poglajen G, Lezaic L, et al. Effects of intracoronary CD34+ stem cell transplantation in nonischemic dilated cardiomyopathy patients: 5-year follow-up. Circ Res 2013;112:165-73. CrossRef

100.Vrtovec B, Sever M, Jensterle M, et al. Efficacy of CD34+ stem cell therapy in nonischemic dilated cardiomyopathy is absent in patients with diabetes but preserved in patients with insulin resistance. Stem Cells Transl Med 2016;5:632-8. CrossRef

101. Kehat I, Kenyagin-Karsenti D, Snir M, et al. Human embryonic stem cells can differentiate into myocytes with structural and functional properties of cardiomyocytes. J Clin Invest 2001;108:407-14. CrossRef

102. Boheler KR, Czyz J, Tweedie D, Yang HT, Anisimov SV, Wobus AM. Differentiation of pluripotent embryonic stem cells into cardiomyocytes. Circ Res 2002;91:189-201. CrossRef

103. Hartman ME, Dai DF, Laflamme MA. Human pluripotent stem cells: prospects and challenges as a source of cardiomyocytes for in vitro modeling and cell-based cardiac repair. Adv Drug Deliv Rev 2016; 96:3-17. CrossRef

104. Takahashi K, Yamanaka S. Induction of pluripotent stem cells from mouse embryonic and adult fibroblast cultures by defined factors. Cell 2006;126:663-76. $\underline{\text { CrossRef }}$
105. Yu J, Vodyanik MA, Smuga-Otto K, et al. Induced pluripotent stem cell lines derived from human somatic cells. Science 2007;318:1917-20. CrossRef

106.Zhang J, Wilson GF, Soerens AG, et al. Functional cardiomyocytes derived from human induced pluripotent stem cells. Circ Res 2009;104:e30-41. CrossRef

107. Lee JH, Lee JB, Shapovalova Z, et al. Somatic transcriptome priming gates lineage-specific differentiation potential of human-induced pluripotent stem cell states. Nat Commun 2014;5:5605. CrossRef

108. Levenberg S, Ferreira LS, Chen-Konak L, Kraehenbuehl TP, Langer R. Isolation, differentiation and characterization of vascular cells derived from human embryonic stem cells. Nat Protoc 2010;5:1115-26. CrossRef

109. Duelen R, Sampaolesi M. Stem cell technology in cardiac regeneration: a pluripotent stem cell promise. EBioMedicine 2017;16:30-40. $\underline{\text { CrossRef }}$

110. Cyranoski D. 'Reprogrammed' stem cells approved to mend human hearts for the first time. Nature 2018; 557:619-20. $\underline{\text { CrossRef }}$

111. Kempf H, Olmer R, Kropp C, et al. Controlling expansion and cardiomyogenic differentiation of human pluripotent stem cells in scalable suspension culture. Stem Cell Reports 2014;3:1132-46. CrossRef

112. Chullikana A, Majumdar AS, Gottipamula S, et al. Randomized, double-blind, phase I/II study of intravenous allogeneic mesenchymal stromal cells in acute myocardial infarction. Cytotherapy 2015;17:250-61. CrossRef

113. Lee J-W, Lee S-H, Youn Y-J, et al. A randomized, open-label, multicenter trial for the safety and efficacy of adult mesenchymal stem cells after acute myocardial infarction. J Korean Med Sci 2014;29:23-31. CrossRef

114. Bartolucci J, Verdugo FJ, Gonzalez PL, et al. Safety and efficacy of the intravenous infusion of umbilical cord mesenchymal stem cells in patients with heart failure: a phase $1 / 2$ randomized controlled trial (RIMECARD Trial [Randomized Clinical Trial of Intravenous Infusion Umbilical Cord Mesenchymal Stem Cells on Cardiopathy]). Circ Res 2017;121:1192204. CrossRef

115. Kim SH, Cho JH, Lee $\mathrm{YH}$, et al. Improvement in left ventricular function with intracoronary mesenchymal stem cell therapy in a patient with anterior wall STsegment elevation myocardial infarction. Cardiovasc Drugs Ther 2018;32:329-38. CrossRef

116. Malliaras K, Makkar RR, Smith RR, et al. Intracoronary cardiosphere-derived cells after myocardial infarction: evidence of therapeutic regeneration in the final 1-year results of the CADUCEUS trial 
(CArdiosphere-Derived aUtologous stem CElls to reverse ventricUlar dySfunction). J Am Coll Cardiol 2014;63:110-22. CrossRef

117. Bollini S, Silini AR, Banerjee A, Wolbank S, Balbi C, Parolini O. Cardiac restoration stemming from the placenta tree: insights from fetal and perinatal cell biology. Front Physiol 2018;9:385. CrossRef

118. Vadakke-Madathil S, LaRocca G, Raedschelders K, et al. Multipotent fetal-derived Cdx2 cells from placenta regenerate the heart. Proc Natl Acad Sci U S A 2019; 116:11786-95. $\underline{\text { CrossRef }}$

119. Hass R, Kasper C, Bohm S, Jacobs R. Different populations and sources of human mesenchymal stem cells (MSC): a comparison of adult and neonatal tissuederived MSC. Cell Commun Signal 2011;9:12. CrossRef

120. Amable PR, Teixeira MV, Carias RB, Granjeiro JM, Borojevic R. Protein synthesis and secretion in human mesenchymal cells derived from bone marrow, adipose tissue and Wharton's jelly. Stem Cell Res Ther 2014;5:53. CrossRef

121. Ayatollahi M, Talaei-Khozani T, Razmkhah M. Growth suppression effect of human mesenchymal stem cells from bone marrow, adipose tissue, and Wharton's jelly of umbilical cord on PBMCs. Iran J Basic Med Sci 2016;19:145-53.

122. Karaoz E, Cetinalp Demircan P, Erman G, Gungorurler E, Eker Sariboyaci A. Comparative analyses of immunosuppressive characteristics of bone-marrow, Wharton's jelly, and adipose tissuederived human mesenchymal stem cells. Turk J Haematol 2017;34:213-25. CrossRef

123. Ribeiro A, Laranjeira P, Mendes S, et al. Mesenchymal stem cells from umbilical cord matrix, adipose tissue and bone marrow exhibit different capability to suppress peripheral blood $\mathrm{B}$, natural killer and $\mathrm{T}$ cells. Stem Cell Res Ther 2013;4:125.

124. Perin L, Sedrakyan S, Da Sacco S, De Filippo R. Characterization of human amniotic fluid stem cells and their pluripotential capability. Methods Cell Biol 2008;86:85-99. CrossRef

125. Savickiene J, Treigyte G, Baronaite S, et al. Human amniotic fluid mesenchymal stem cells from secondand third-trimester amniocentesis: differentiation potential, molecular signature, and proteome analysis. Stem Cells Int 2015;2015:319238. CrossRef

126. Roubelakis MG, Pappa KI, Bitsika V, et al. Molecular and proteomic characterization of human mesenchymal stem cells derived from amniotic fluid: comparison to bone marrow mesenchymal stem cells. Stem Cells Dev 2007;16:931-52. CrossRef

127. Pires AO, Mendes-Pinheiro B, Teixeira FG, et al. Unveiling the differences of secretome of human bone marrow mesenchymal stem cells, adipose tissuederived stem cells, and human umbilical cord perivascular cells: a proteomic analysis. Stem Cells Dev 2016;25:1073-83. $\underline{\text { CrossRef }}$

128. Urbich C, Aicher A, Heeschen C, et al. Soluble factors released by endothelial progenitor cells promote migration of endothelial cells and cardiac resident progenitor cells. J Mol Cell Cardiol 2005;39:733-42. $\underline{\text { CrossRef }}$

129. Adamiak M, Cheng G, Bobis-Wozowicz S, et al. Induced pluripotent stem cell (iPSC)-derived extracellular vesicles are safer and more effective for cardiac repair than iPSCs. Circ Res 2018;122:296309. CrossRef

130. Kervadec A, Bellamy V, El Harane N, et al. Cardiovascular progenitor-derived extracellular vesicles recapitulate the beneficial effects of their parent cells in the treatment of chronic heart failure. J Heart Lung Transplant 2016;35:795-807. CrossRef

131. da Silva Meirelles L, Caplan AI, Nardi NB. In search of the in vivo identity of mesenchymal stem cells. Stem Cells 2008;26:2287-99. $\underline{\text { CrossRef }}$

132. Huang L, Ma W, Ma Y, Feng D, Chen H, Cai B. Exosomes in mesenchymal stem cells, a new therapeutic strategy for cardiovascular diseases? Int J Biol Sci 2015;11:238-45. CrossRef

133. Arslan F, Lai RC, Smeets MB, et al. Mesenchymal stem cell-derived exosomes increase ATP levels, decrease oxidative stress and activate $\mathrm{PI}_{3} \mathrm{~K} /$ Akt pathway to enhance myocardial viability and prevent adverse remodeling after myocardial ischemia/reperfusion injury. Stem Cell Res 2013;10:301-12. $\underline{\text { CrossRef }}$

134. Lai RC, Arslan F, Lee MM, et al. Exosome secreted by MSC reduces myocardial ischemia/reperfusion injury. Stem Cell Res 2010;4:214-22. $\underline{\text { CrossRef }}$

135. Barile L, Lionetti V, Cervio E, et al. Extracellular vesicles from human cardiac progenitor cells inhibit cardiomyocyte apoptosis and improve cardiac function after myocardial infarction. Cardiovasc Res 2014;103:530-41. $\underline{\text { CrossRef }}$

136. Zhang M, Methot D, Poppa V, Fujio Y, Walsh K, Murry CE. Cardiomyocyte grafting for cardiac repair: graft cell death and anti- death strategies. J Mol Cell Cardiol 2001;33:907-21. CrossRef

137. Sheikh AY, Lin SA, Cao F, et al. Molecular imaging of bone marrow mononuclear cell homing and engraftment in ischemic myocardium. Stem Cells 2007;25: 2677-84. CrossRef

138. Reis LA, Chiu LL, Feric N, Fu L, Radisic M. Biomaterials in myocardial tissue engineering. J Tissue Eng Regen Med 2016;10:11-28. $\underline{\text { CrossRef }}$ 
139. Marquardt LM, Heilshorn SC. Design of injectable materials to improve stem cell transplantation. Curr Stem Cell Rep 2016;2:207-20. CrossRef

140. Ban K, Park HJ, Kim S, et al. Cell therapy with embryonic stem cell-derived cardiomyocytes encapsulated in injectable nanomatrix gel enhances cell engraftment and promotes cardiac repair. ACS Nano 2014;8:10815-25. $\underline{\text { CrossRef }}$

141. Chow A, Stuckey DJ, Kidher E, et al. Human induced pluripotent stem cell-derived cardiomyocyte encapsulating bioactive hydrogels improve rat heart function post myocardial infarction. Stem Cell Reports 2017;9:1415-22. CrossRef

142. Mohanty S, Larsen LB, Trifol J, et al. Fabrication of scalable and structured tissue engineering scaffolds using water dissolvable sacrificial $3 \mathrm{D}$ printed moulds. Mater Sci Eng C Mater Biol Appl 2015;55:569-78. CrossRef

143. Levit RD, Landazuri N, Phelps EA, et al. Cellular encapsulation enhances cardiac repair. J Am Heart Assoc 2013;2:e000367. CrossRef

144. Ribeiro AJ, Ang YS, Fu JD, et al. Contractility of single cardiomyocytes differentiated from pluripotent stem cells depends on physiological shape and substrate stiffness. Proc Natl Acad Sci U S A 2015;112: 12705-10. CrossRef

145. Gallet R, Dawkins J, Valle J, et al. Exosomes secreted by cardiosphere-derived cells reduce scarring, attenuate adverse remodelling, and improve function in acute and chronic porcine myocardial infarction. Eur Heart J 2017;38:201-11. CrossRef
146. Shao L, Zhang Y, Lan B, et al. MiRNA-sequence indicates that mesenchymal stem cells and exosomes have similar mechanism to enhance cardiac repair. Biomed Res Int 2017;2017:4150705.

147. Tokita Y, Tang XL, Li Q, et al. Repeated administrations of cardiac progenitor cells are markedly more effective than a single administration: a new paradigm in cell therapy. Circ Res 2016;119:635-51. CrossRef

148. Florea V, Rieger AC, Natsumeda M, et al. The impact of patient sex on the response to intramyocardial mesenchymal stem cell administration in patients with non-ischemic dilated cardiomyopathy. Cardiovasc Res 2020 Feb 13. [Epub ahead of print] CrossRef

149. Golpanian S, El-Khorazaty J, Mendizabal A, et al. Effect of aging on human mesenchymal stem cell therapy in ischemic cardiomyopathy patients. $\mathrm{J}$ Am Coll Cardiol 2015;65:125-32. CrossRef

150. Luu B, Leistner DM, Herrmann E, et al. Minute myocardial injury as measured by high-sensitive troponin T serum levels predicts the response to intracoronary infusion of bone marrow-derived mononuclear cells in patients with stable chronic post-infarction heart failure: insights from the TOPCARE-CHD registry. Circ Res 2017;120:1938-46. CrossRef

151. Borow KM, Yaroshinsky A, Greenberg B, Perin EC. Phase 3 DREAM-HF trial of mesenchymal precursor cells in chronic heart failure. Circ Res 2019;125:26581. $\underline{\text { CrossRef }}$ 